\title{
OPTIMALISASI TEKNOLOGI ENERGI SURYA BERBASIS PENYESUAIAN POSISI PANEL BULANAN DI SULAWESI TENGGARA
}

\author{
Aditya Rachman \\ Staf Pengajar Program Studi Teknik Mesin Fakultas Teknik Universitas Halu Oleo, Kendari \\ Kampus Hijau Bumi Tridarma Andounohu Kendari 93232 \\ *E-mail : aditya_rchmn@yahoo.com
}

Diterima: 7 September 2015

Direvisi: 20 Oktober 2015

Disetujui: 8 Desember 2015

\begin{abstract}
ABSTRAK
Tujuan dari penelitian ini adalah untuk mengoptimalkan teknologi PV surya dengan menggunakan metode penyesuaian posisi panel bulanan di Sulawesi Tenggara. Studi ini mensimulasikan jumlah energi tahunan dari metode yang diusulkan dengan menggunakan model matematika radiasi matahari yang jatuh pada permukaan miring, yang dikombinasikan dengan data radiasi global matahari, yang diperoleh dari NASA Langley Research Center Atmospheric Science Data Center Surface Meteorological and Solar Energy (SSE) web portal supported by the NASA LaRC POWER Project dengan menggunakan data pada bulan Juliy 1983 sampai Juni 2005. Hasil penelitian ini menunjukkan bahwa pada bulan Januari, arah panel optimal adalah di selatan dengan sudut kemiringan $25^{\circ}$. Pada bulan Februari, sudut optimal bergeser ke $15^{\circ}$, pada arah yang sama dengan sebelumnya, dan pada bulan Maret, sudut optimal adalah sejajar dengan permukaan bumi. Pada bulan April sampai September, sudut optimal berkisar dari $15^{\circ}$ sampai $35^{\circ}$ ke arah utara, sedangkan pada bulan Oktober sampai Desember, sudut optimal berkisar dari $10^{\circ}$ sampai $25^{\circ}$ ke arah selatan. Konfigurasi teknologi surya dengan penyesuaian sudut panel optimal bulanan dapat meningkatkan energi tahunan yang dihasilkan sebesar 10 persen, dibandingkan dengan metode sudut panel tetap.
\end{abstract}

Katakunci : panel surya, optimasi, pengaturan bulanan, sudut, arah

\begin{abstract}
The aim of this study is to optimize the PV-Solar technology using the method of monthly optimum panel position adjustment in Southeast Sulawesi. It simulates the annual energy generation from the proposed method using the mathematical model of the solar radiation falling on a tilted surface, being combined with the data of the solar global radiation, obtained from the NASA Langley Research Center Atmospheric Science Data Center Surface Meteorological and Solar Energy (SSE) web portal supported by the NASA LaRC POWER Project using data of July 1983 to June 2005. The result shows that in January, the optimum direction is at South with the optimum tilt angle of $25^{\circ}$. In February, the optimum angle shifts to $15^{\circ}$, at the same previous direction, and in March, it is parallel to the earth surface. In April to September, the optimum angles range from $15^{\circ}$ to $35^{\circ}$ in the North direction, while in October to December, the optimum angles range from $10^{\circ}$ to $25^{\circ}$ in the South direction. The solar configuration with monthly optimum angle adjustment can enhance the annual energy generated, by 10 percent, relative to that with the fixed angle method.
\end{abstract}

Keywords: solar panel, optimization, monthly adjustment, pitch, direction 


\section{PENDAHULUAN}

Untuk Sulawesi Tenggara, daerah yang sedang berkembang di bagian timur Indonesia, dengan rasio listrik dan konsumsi listrik per kapita yang masih rendah, pengembangan energi terbarukan berdasarkan energi surya dapat menjadi pilihan yang menjanjikan. Posisi dekat dengan garis khatulistiwa dapat membawa manfaat yang banyak untuk provinsi ini dalam memperoleh radiasi energi matahari (Balaka dkk, 2013, Sudia dkk, 2011).

Kinerja merupakan salah satu aspek penting dalam penerapan teknologi surya di provinsi ini. Kinerja tinggi sangat diinginkan untuk mendapatkan daya tarik ekonomis dalam aplikasi teknologi ini. Optimasi posisi panel surya adalah salah satu metode untuk mendapatkan kinerja tinggi. Salah satu optimasi posisi panel yang sederhana adalah dengan mengatur sudut dan arah panel berdasarkan periode waktu tertentu, seperti bulanan dan musiman.

George dkk (2012) menyelidiki konfigurasi dari panel PV surya berdasarkan sudut kemiringan bulanan dan musiman yang optimal di Kerala India dengan menggunakan metode faktor geografis, metode indeks kejelasan dan metode sudut deklinasi. Hasil penelitian menunjukkan bahwa menyesuaikan panel berdasarkan sudut optimum bulanan dapat menghasilkan energi 3 persen lebih besar dari pada optimasi panel berdasarkan sudut musiman.

Sebuah studi di Handoyo dkk (2013) menunjukkan bahwa pada kolektor surya yang dipasang di Surabaya, pada bulan Maret sampai September, sudut kemiringan optimum berkisar dari $0^{\circ}$ sampai $40^{\circ}$ ke arah utara, sedangkan pada bulan Oktober sampai Maret, sudut optimum berkisar dari $0^{\circ}$ sampai $30^{\circ}$ ke arah selatan. Benghanem (2011) mengoptimalkan konfigurasi dari panel surya berdasarkan sudut kemiringan perubahan bulanan untuk mengumpulkan radiasi matahari maksimum dengan menggunakan data radiasi global harian di Medinah Arab Saudi. Hasil studi menunjukkan bahwa menyesuaikan panel berdasarkan sudut kemiringan optimal bulanan dapat meningkatkan energi tahunan sekitar 8 persen, relatif terhadap panel dengan sudut tetap.

Sebuah studi di Liu (2012) menunjukkan bahwa penyesuaian kolektor surya berdasarkan sudut kemiringan optimum bulanan dapat memperoleh energi tahunan yang lebih tinggi dari kolektor dengan sudut tetap. Dengan menggunakan model matematika, sebuah penelitian di Azmi dkk (2001) mengungkapkan bahwa perubahan pada sudut kemiringan bulanan dalam setahun pada kolektor surya dapat meningkatkan radiasi sebesar 5 persen di lokasi di Brunei Darussalam, relatif terhadap kolektor horisontal tetap. Sebuah studi di Gunerhan dkk (2007) menunjukkan bahwa penyesuaian panel surya bulanan dapat meningkatkan efisiensi teknologi surya. Idowu dkk (2013) mengoptimalkan sudut kemiringan pada kolektor surya di daerah dengan garis lintang $1^{\circ}$ sampai $14^{\circ}$ dengan menggunakan persamaan radiasi matahari dari satu set data yang tercatat pada pyranometer di lokasi di utara khatulistiwa. Studi ini menunjukkan bahwa sudut kemiringan optimal adalah berbeda-beda setiap bulan. Sebuah studi di Kacira dkk (2004) menunjukkan bahwa sudut kemiringan optimal bulanan untuk panel surya di Sanliurfa Turki adalah bervariasi sepanjang tahun. Pada bulan Juni, sudut kemiringan optimal di 13 ', sementara pada bulan Desember, sudutnya adalah $61^{\circ}$, di arah Selatan.

Kondisi geografi dapat menjadi salah satu aspek penting yang dibutuhkan untuk dipertimbangkan dalam merancang strategi dalam menerapkan teknologi pembangkit surya di Sulawesi Tenggara, yang mungkin banyak berbeda dengan strategi-strategi dalam referensi sebelumnya. Hal ini didorong oleh fakta bahwa Sulawesi Tenggara terletak di daerah di mana tidak hanya matahari yang terlihat bergerak dari timur ke barat setiap harinya, tetapi juga, jalurnya terlihat bergeser di selatan ke utara bergantian setiap tahunnya. Pada bulan Oktober sampai Maret, matahari terlihat di belahan bumi selatan, sementara, pada bulan April sampai September, matahari terlihat di bagian utara dunia. Alasan untuk fenomena ini adalah lokasi wilayah Sulawesi Tenggara yang sangat dekat dengan garis khatulistiwa (pada garis lintang sekitar $4^{\circ}$ sampai $6^{\circ}$ ).

Sebuah referensi dalam Duffie dkk (1991) menunjukkan perubahan dari jalur matahari dalam setahun ke arah lintang (arah selatan-utara). Dalam referensi ini, kisaran pergerakan jalur matahari adalah dari $23^{\circ} 0,26$ 'Lintang Utara sampai $23^{\circ} 0,26^{\prime}$ Lintang Selatan. Dengan demikian, daerah dalam kisaran ini mungkin melihat perubahan jalur 
surya ke arah utara-selatan setiap tahun, seperti di Sulawesi Tenggara, sementara, untuk daerah di luar jangkauan, gerakan matahari mungkin hanya terlihat di sisi utara saja atau sisi selatan saja.

Tujuan dari penelitian ini adalah untuk mengoptimalkan teknologi PV surya di Sulawesi Tenggara dengan menggunakan metode sudut dan arah panel optimum berdasarkan penyesuaian periode waktu.

\section{METODOLOGI}

Penelitian ini menggunakan model matematika dari radiasi matahari yang jatuh pada permukaan bidang miring. Pada bagian berikut, akan dijelaskan tentang pengembangan model ini.

Total rata-rata radiasi matahari harian pada permukaan bidang miring $\left(\mathrm{H}_{\mathrm{T}}\right)$ dapat diperkirakan dengan mempertimbangkan secara individual radiasi langsung $\left(\mathrm{H}_{\mathrm{B}}\right)$, radiasi difuse $\left(\mathrm{H}_{\mathrm{D}}\right)$ dan radiasi pantul $\left(\mathrm{H}_{\mathrm{R}}\right)$ (Benghanem, 2011). Dengan demikian, untuk permukaan miring, insiden radiasi keseluruhan $\left(\mathrm{H}_{\mathrm{T}}\right)$ ( $\mathrm{KWH} / \mathrm{m}^{2}$ hari) dapat diturunkan dengan

$$
\mathrm{H}_{\mathrm{T}}=\mathrm{H}_{\mathrm{B}}+\mathrm{H}_{\mathrm{D}}+\mathrm{H}_{\mathrm{R}}
$$

dimana, $\mathrm{H}_{\mathrm{B}}$ (radiasi sinar harian langsung yang diterima pada permukaan miring $\left(\mathrm{KWH} / \mathrm{m}^{2}-\right.$ hari) dapat dinyatakan sebagai

$$
\mathrm{H}_{\mathrm{B}}=\left(\mathrm{H}_{\mathrm{g}}-\mathrm{H}_{\mathrm{d}}\right) \frac{\cos (\theta)}{\cos \theta_{\mathrm{z}}}
$$

$\mathrm{Hg}$ dan $\mathrm{Hd}$ adalah radiasi rata-rata harian global dan radiasi difus pada permukaan horisontal $\left(\mathrm{KWH} / \mathrm{m}^{2}\right.$-hari), dan $\theta$ adalah sudut datang $\left(^{\circ}\right)$, yang dapat diperoleh dari persamaan berikut (Duffie dkk, 1991 \& McQuiston dkk, 2004 ) (lihat Gambar 1)

$$
\begin{aligned}
\cos \theta= & \sin \delta \sin \Phi \cos \beta-\sin \delta \cos \Phi \sin \beta \cos \gamma \\
& +\cos \delta \cos \Phi \cos \beta \cos (1) \\
& +\cos \delta \sin \beta \sin \gamma \sin (1) \\
& +\cos \delta \sin \Phi \sin \beta \cos \gamma \cos (1)
\end{aligned}
$$

$\theta \mathrm{z}$ adalah sudut zenit $\left({ }^{\circ}\right)$, yang dapat ditentukan dengan persamaan berikut

$\cos \theta_{\mathrm{z}}=\cos \Phi \cos \delta \cos \omega+\sin \Phi \sin \delta$

$\omega$ adalah sudut jam $\left(^{\circ}\right)$, yang merupakan perpindahan sudut matahari timur atau barat dari meridian lokal karena rotasi bumi pada porosnya pada $15^{\circ}$ per jam, $\varphi$ adalah sudut lintang $\left(^{\circ}\right)$, yang merupakan sudut lokasi utara atau selatan dari khatulistiwa, $\beta$ adalah sudut kemiringan permukaan panel $\left(^{\circ}\right)$ dan $\gamma$ adalah sudut azimuth permukaan $\left({ }^{\circ}\right)$, yang merupakan sudut horisontal antara selatan dan arah permukaan perangkat (McQuiston dkk, 2004 ).

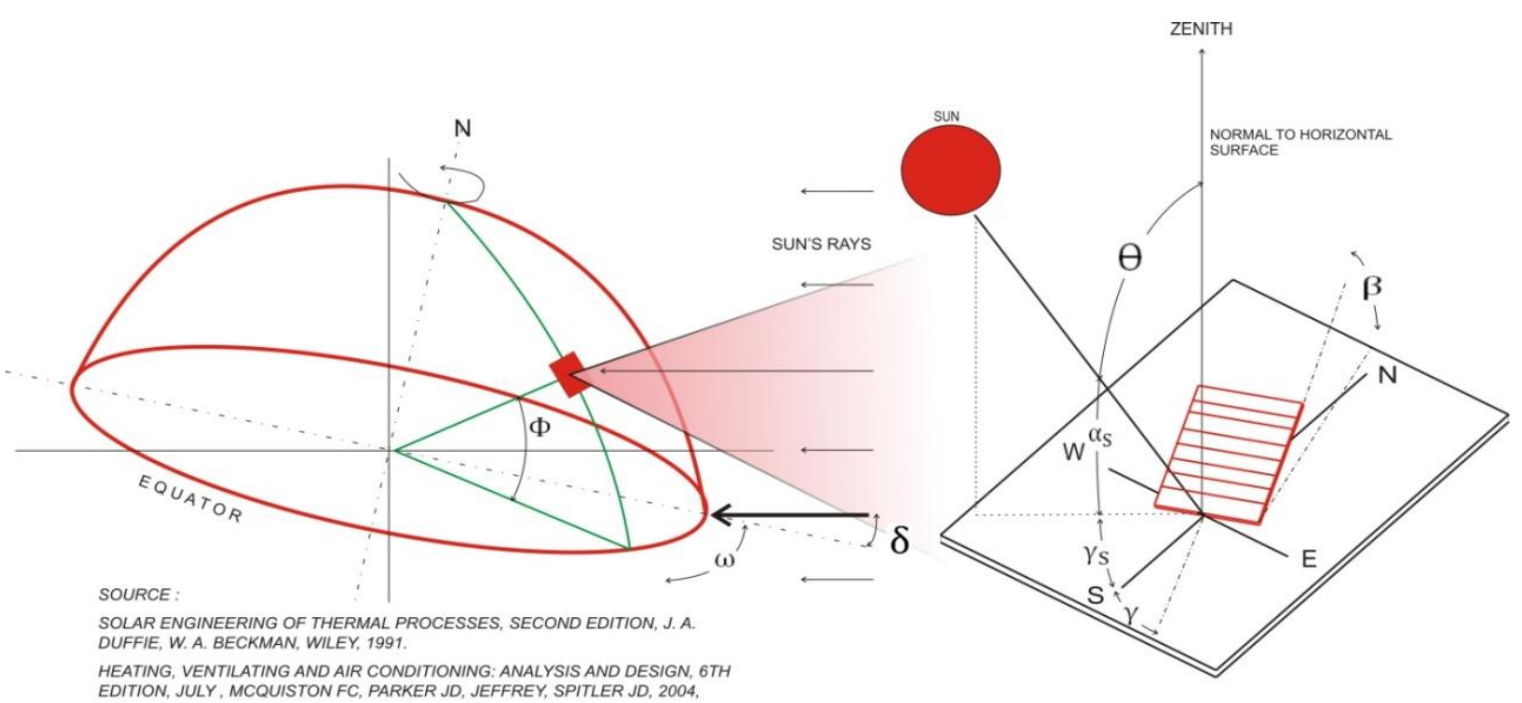

Gambar 1. Beberapa parameter yang menentukan sudut datang matahari pada permukaan miring 
Parameter dari $\delta$ adalah sudut deklinasi posisi sudut matahari di siang hari terhadap bidang ekuator $\left(-23^{\circ} 0,26^{\prime} \leq \delta \leq 23^{\circ} 0,26^{\prime}\right)\left({ }^{\circ}\right)$. Sudut deklinasi dapat ditentukan dari persamaan berikut

$\delta=23.45 \sin \left(360 \frac{284+\mathrm{n}}{365}\right)$

Di mana $\mathrm{n}$ adalah hari dalam setahun.

$\mathrm{H}_{\mathrm{D}}\left(\mathrm{KWH} / \mathrm{m}^{2}\right.$-hari $)$, dirumuskan oleh

$H_{D}=H_{g} \rho \frac{(1-\cos \beta)}{2}$

Dimana , $\rho$ adalah ground albedo.

$\mathrm{HR}\left(\mathrm{KWH} / \mathrm{m}^{2}\right.$-hari), dirumuskan oleh

$$
\mathrm{H}_{\mathrm{R}}=\mathrm{H}_{\mathrm{d}} \mathrm{R}_{\mathrm{d}}
$$

$\mathrm{Rd}$ adalah rasio rata-rata radiasi difus harian pada permukaan miring, terhadap permukaan horisontal. Metode untuk memperkirakan rasio ini dapat diklasifikasikan sebagai model isotropik dan anisotropik. Model isotropik mengasumsikan keseragaman intensitas radiasi langit menyebar di atas langit kubah, sedangkan model anisotropic menganggap anisotropi dari radiasi langit menyebar di wilayah circumsolar (langit dekat piringan matahari) dan komponen menyebar didistribusikan secara isotropis dari yang lain pada langit kubah (Benghanem, 2011).

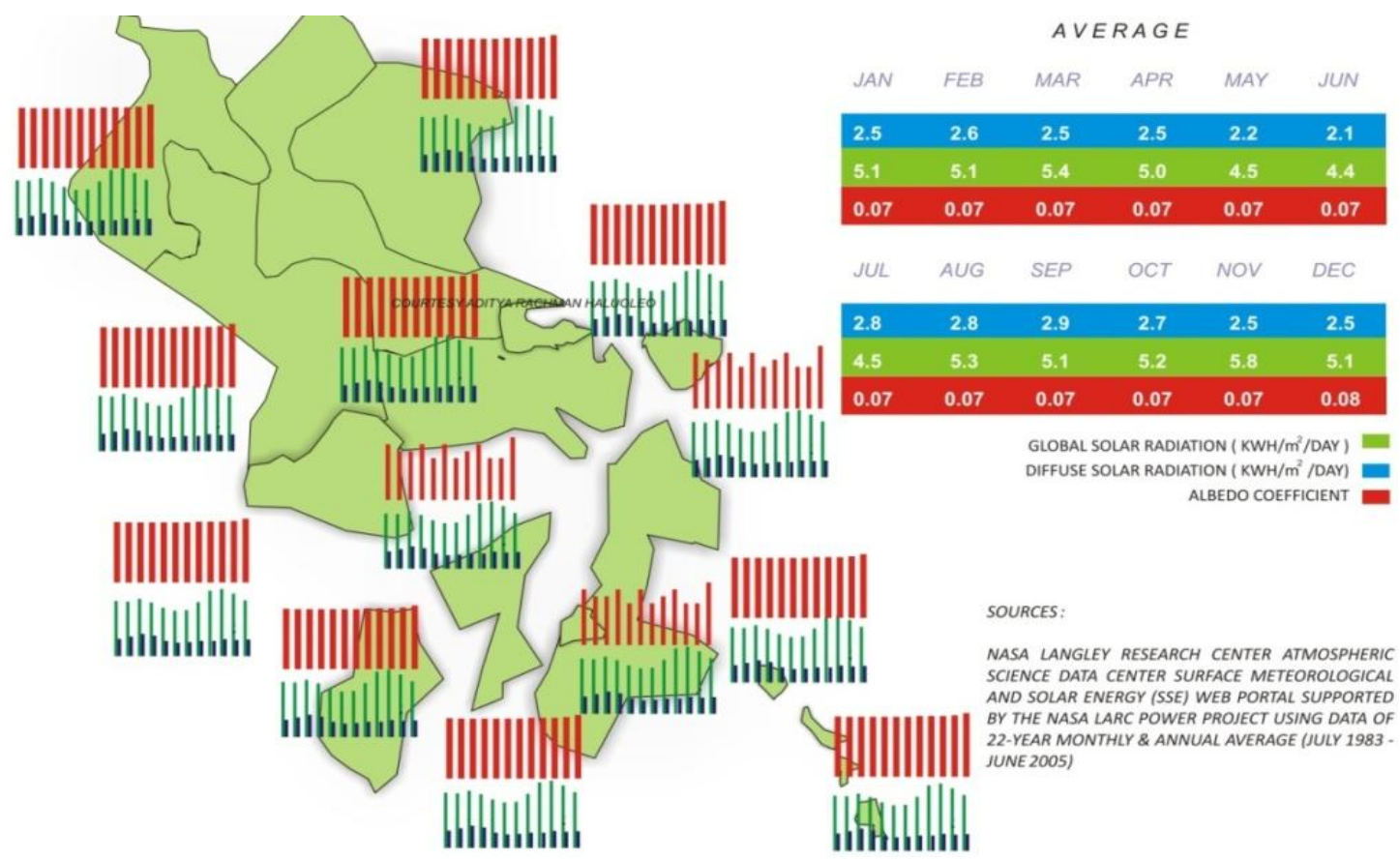

Gambar 2. Radiasi matahari harian global dan difus (menyebar) rata-rata dan albedo-ground di Kabupaten dan Kota di Sulawesi Tenggara (NASA, 2014) 
Dalam model Isotropis (Model Liu dan Jordan, 1961), Rd diberikan sebagai berikut

$$
\mathrm{R}_{\mathrm{d}}=\frac{1+\cos (\beta)}{2}
$$

Dalam model Anisotropis, (Model Hay, 1979), $\mathrm{Rd}$ diberikan oleh relasi

$\mathrm{R}_{\mathrm{d}}=\frac{\mathrm{H}_{\mathrm{b}}}{\mathrm{H}_{0}} \frac{\cos \theta}{\cos \theta_{\mathrm{z}}}+\left(1-\frac{\mathrm{H}_{\mathrm{b}}}{\mathrm{H}_{0}}\right)+\left(\frac{1+\cos (\beta)}{2}\right)$

Dimana, $\mathrm{H}_{\mathrm{b}}$ adalah insiden radiasi harian pada permukaan horisontal $\left(\mathrm{KWH} / \mathrm{m}^{2}\right.$-hari), yang dirumuskan oleh

$$
\mathrm{H}_{\mathrm{b}}=\mathrm{H}_{0}\left(1+0.033 \cos \left(\frac{360 \mathrm{n}}{365}\right)\right)
$$

$\mathrm{H}_{0}$ adalah insiden radiasi ekstra-terestrial harian pada permukaan horisontal (KWH / $\mathrm{m}^{2}$-hari), yang dirumuskan oleh

$$
\begin{array}{r}
H_{0}=\frac{24 \times 3600 \times 1367}{\pi}\left(1+0.033 \cos \left(\frac{360 \mathrm{n}}{365}\right)\right) \\
\times \quad\left(\cos \phi \cos \delta \sin \omega_{\mathrm{z}}+\frac{2 \pi \omega_{\mathrm{z}}}{360} \sin \phi \sin \delta\right)
\end{array}
$$

Dimana, $\omega_{\mathrm{z}}$ adalah sudut matahari terbenam $\left(^{\circ}\right)$, yang dapat diperoleh dari

$$
\cos \omega_{\mathrm{z}}=-\tan \Phi \tan \delta
$$

Hasil radiasi harian matahari dari perhitungan di atas, digunakan untuk menentukan energi bulanan dan tahunan yang dihasilkan dari teknologi surya dengan mempertimbangkan efisiensi dan persentase kecerahan sinar matahari.

Dalam penelitian ini, data dari radiasi global harian, radiasi matahari harian difus dan ground-albedo diperoleh dari NASA Langley Research Center Atmospheric Science Data Center Surface meteorological and Solar Energy (SSE) web portal yang didukung oleh NASA LaRC POWER Project dengan menggunakan data radiasi matahari rata-rata selama 22 tahun (Juli 1983 - Juni 2005). Data dari 13 lokasi di Sulawesi Tenggara (berdasarkan garis lintang dan bujur) dikumpulkan, kemudian, di-rata-ratakan untuk digunakan sebagai dasar untuk menghitung energi tenaga surya yang dihasilkan dengan menggunakan persamaan (1). Untuk mensimulasikan beberapa output pada kajian ini, diasumsikan bahwa efisiensi teknologi surya secara keseluruhan adalah 10 persen.

\section{HASIL DAN DISKUSI}

Gambar 4 menunjukkan arah dan kemiringan sudut optimal kolektor surya PV berdasarkan penyesuaian bulanan. Pada bulan Januari, arah optimal adalah di selatan dengan sudut kemiringan $25^{\circ}$. Sudut optimum ini bergeser ke $15^{\circ}$, pada arah yang sama, pada bulan Februari. Pada bulan Maret, sudut kemiringan optimal adalah pada $0^{\circ}$. Pada bulan April sampai September, sudut optimal berkisar dari $15^{\circ}$ sampai $35^{\circ}$ ke arah utara, sedangkan pada bulan Oktober sampai Desember, sudut optimal berkisar dari $10^{\circ}$ sampai $25^{\circ}$ ke arah selatan. Perubahan dalam sudut miring dan arah bulanan adalah dalam upaya untuk mendapatkan sebanyak elemen tegak lurus radiasi matahari. Pada bulan Januari, Februari, Oktober, November dan Desember, jalur matahari di selatan belahan bumi, sehingga panel harus diarahkan selatan, sementara pada bulan April, Mei, Juni, Juli, Agustus dan September, jalur surya ada di utara dari dunia, sehingga panel harus diarahkan ke utara (lihat Gambar 4). 


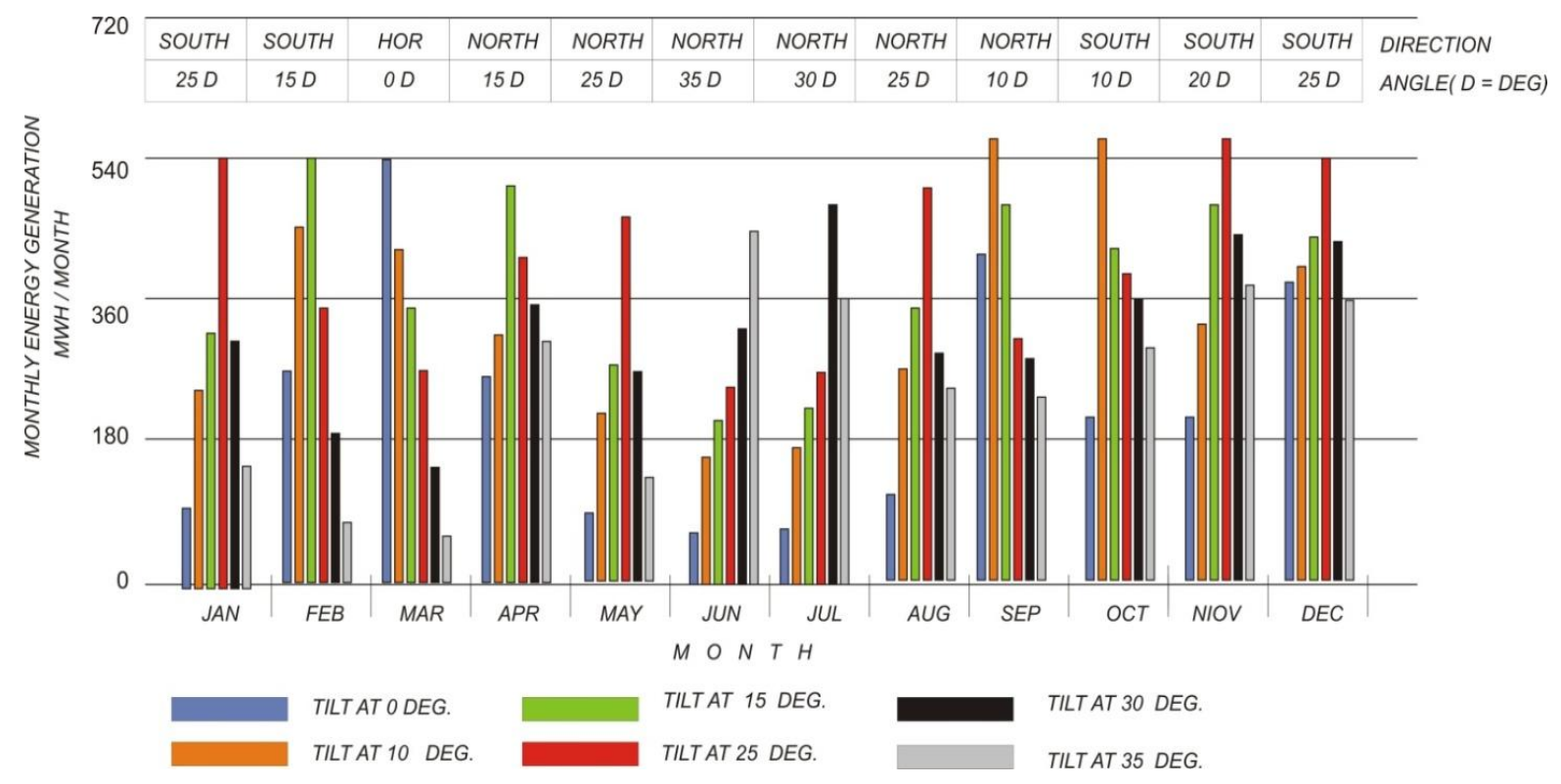

Gambar 3. Arah dan kemiringan sudut optimal kolektor surya PV berdasarkan penyesuaian bulanan

Pada bulan Januari, posisi matahari berada pada $-20,9^{\circ}$, sehingga arah panel optimal adalah sekitar $25^{\circ}$ ke arah Selatan. Pada bulan Februari, posisi matahari berada pada $-13^{\circ}$, sehingga panel harus diarahkan menjadi sekitar $15{ }^{\circ}$ di selatan. Pada bulan Maret, posisi matahari berada di atas kepala, sehingga posisi panel optimal adalah sejajar dengan permukaan bumi.
Ketika bulan berjalan hingga Juni, posisi matahari cenderung ke arah utara. Dalam kondisi ini, orientasi panel harus ke utara. Pada bulan Juli, posisi matahari sedikit bergeser pada $21,2^{\circ}$, sehingga panel diarahkan pada $30^{\circ} \mathrm{di}$ utara. Ketika bulan berjalan, matahari bergeser di selatan lagi, sehingga panel harus diarahkan ke selatan.

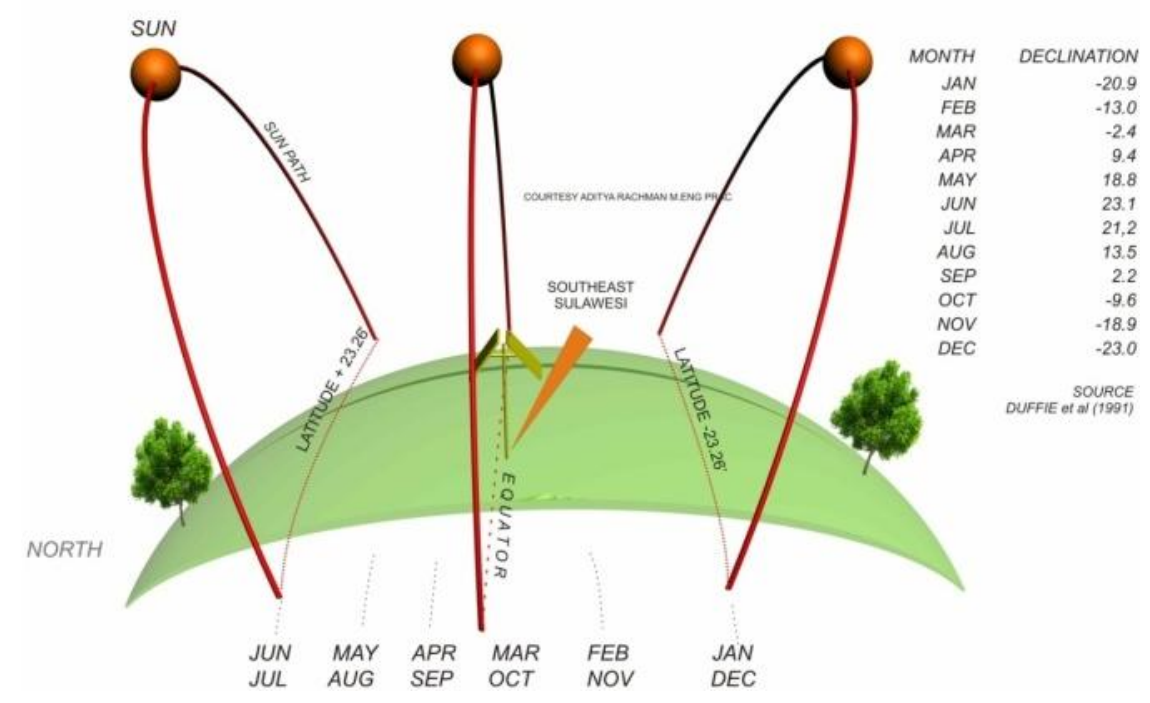

Gambar 4. Posisi jalur matahari dalam satu tahun (Duffie, 1991) 


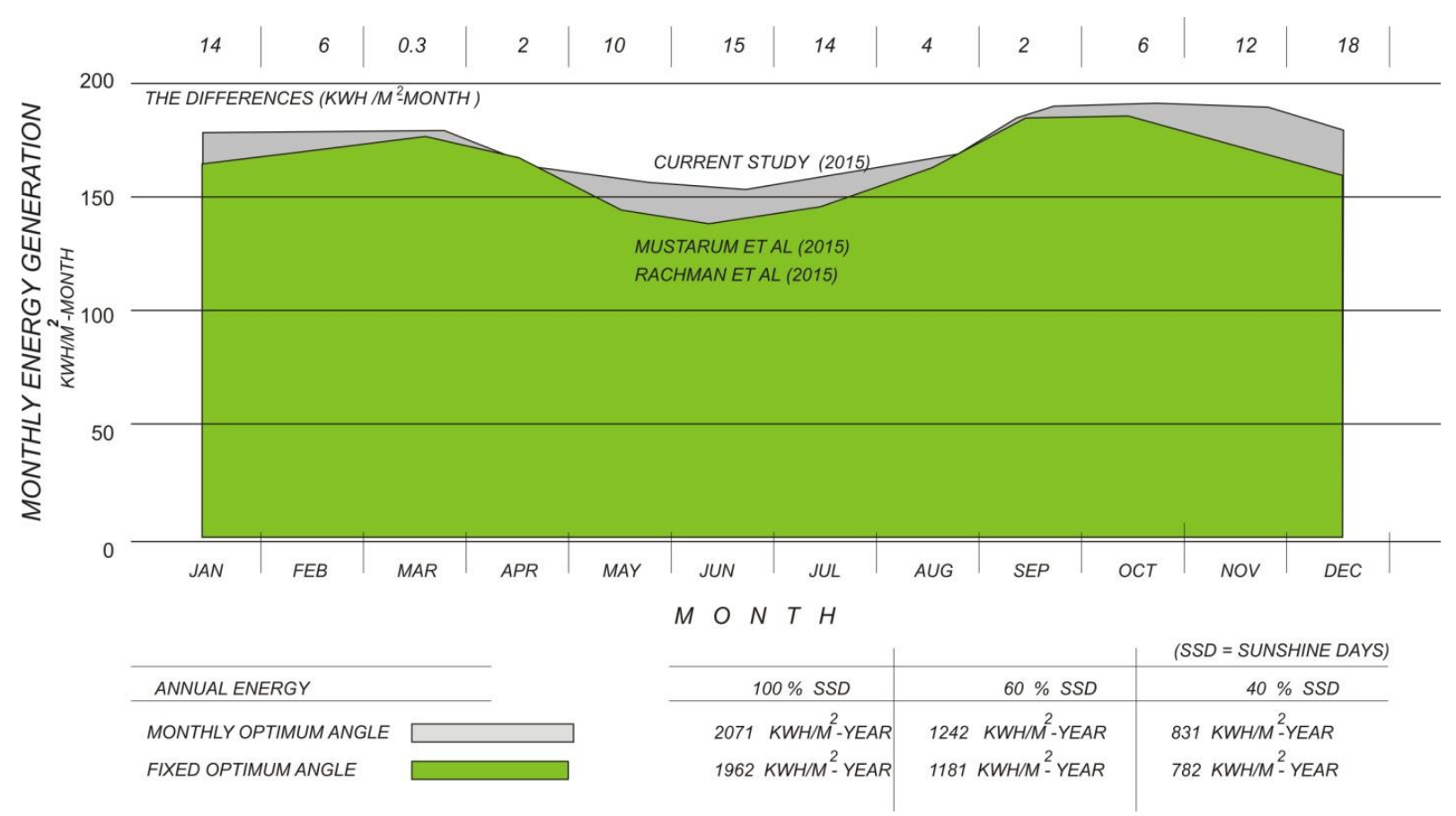

Gambar 5. Perbandingan energi yang dihasilkan dalam kasus optimasi panel tetap (di Mustarum dkk, 2015 dan Rachman dkk, 2015) dengan optimasi panel bulanan

Gambar 5 menunjukkan perbandingan energi yang dihasilkan pada optimasi panel bulanan terhadap optimasi sudut tetap (pada Mustarum dkk, 2015). Hasil ini menunjukkan bahwa konfigurasi surya dengan sudut optimal bulanan dapat meningkatkan energi tahunan yang dihasilkan, relatif terhadap metode sudut tetap. Pada asumsi 100 persen hari cerah, energi yang dihasilkan untuk panel dengan sudut optimum tetap adalah sekitar 1962 $\mathrm{KWH} / \mathrm{m}^{2}$ per tahun, sedangkan konfigurasi optimasi panel bulanan adalah sekitar 2.071 $\mathrm{KWH} / \mathrm{m}^{2}$ per-tahun. Ketika terjadi penurunan persentase hari cerah, energi tahunan yang dihasilkan berkurang juga.

Pada bulan Januari, untuk optimasi bulanan, energi yang dihasilkan adalah sekitar $178 \mathrm{KWH} / \mathrm{m}^{2}$ dengan perbedaan besar terhadap optimasi sudut tetap. Selanjutnya, energi ini menurun hingga $174 \mathrm{KWH} / \mathrm{m}^{2}$ pada bulan Februari sebelum meningkat menjadi 178 $\mathrm{KWH} / \mathrm{m}^{2}$, di bulan berikutnya. Dalam kondisi ini, jumlah energi yang dihasilkan hampir sama dengan yang ada pada optimasi panel tetap. Pada bulan April, sudut optimum sekitar 167 $\mathrm{KWH} / \mathrm{m}^{2}$ dengan masih sedikit perbedaan dengan optimasi tetap. Pada bulan Mei, Juni dan Juli, perbedaan yang lebih jelas, sebelum hampir sama lagi pada bulan Agustus hingga
Oktober. Pada bulan November dan Desember, perbedaan antara optimasi bulanan dan optimasi tetap sangat tinggi.

\section{KESIMPULAN}

Optimasi pada teknologi surya PV di Sulawesi Tenggara berdasarkan penyesuaian panel bulanan telah dilakukan dalam penelitian ini. Berikut adalah kesimpulan yang dapat ditarik. Pada bulan Januari, arah panel optimal ada di selatan dengan sudut kemiringan $25^{\circ}$. Sudut ini berubah menjadi $15^{\circ}$, dengan arah yang sama, pada bulan Februari. Pada bulan Maret, sudut kemiringan optimal adalah sejajar dengan permukaan bumi. Pada bulan April sampai September, sudut optimal berkisar dari $15^{\circ}$ sampai $35^{\circ}$ ke arah utara, sedangkan pada bulan Oktober sampai Desember, sudut optimal berkisar dari $10^{\circ}$ sampai $25^{\circ}$ ke arah selatan. Penerapan konfigurasi panel surya dengan optimasi bulanan dapat meningkatkan energi tahunan yang dihasilkan, relatif terhadap metode sudut tetap (10 persen). 


\section{DAFTAR PUSTAKA}

Azmi MHMY, Malik AQ, 2001. Optimum tilt angle and orientation for solar collector in Brunei Darussalam, Renewable Energy, 24, 2, 223-234

Balaka R, Rachman A, Jaya LDM, 2013. Mitigating climate change through the development of clean renewable energy in Southeast Sulawesi, a developing region in Indonesia, International Journal of Energy, Information and Communications, 4,4

Benghanem M, 2011. Optimization of tilt angle for solar panel: Case study for Madinah, Saudi Arabia, Applied Energy, 88, 4, 1427-1433

Duffie JA, Beckman WA, 1991. Solar engineering of thermal processes, second edition, Wiley.

George A, Coll AY, Kanjirapally, Anto R, 2012. Analytical and experimental analysis of optimal tilt angle of solar photovoltaic systems, Green Technologies (ICGT), International Conference, 234 - 239, DOI : 10.1109/ICGT.2012.6477978

Gunerhan H, Hepbasli A, 2007. Determination of the optimum tilt angle of solar collectors for building applications, Building and Environment, 42, 2, 779783

Handoyo EA, Ichsani D, Prabowo, 2013. The optimal tilt angle of a solar collector, Energy Procedia, 32 , 166 - 175

Hay J, 1979. Calculation of monthly mean solar radiation for horisontal and tilted surfaces. Solar Energy, 23

Idowu OS, Olarenwaju OM, Ifedayo OI, 2013. Determination of optimum tilt angles for solar collectors in low-latitude tropical region, International Journal of Energy and Environmental Engineering, 4 (29), doi:10.1186/2251-6832-4-29

Kacira M, Simsek M, Babur Y, Demirkol S, 2004. Determining optimum tilt angles and orientations of photovoltaic panels in Sanliurfa, Turkey, Renewable Energy, $29,8,1265-1275$
Liu BYH, Jordan RC, 1961. Daily insolation on surfaces tilted toward the equator. ASHRAE, 3, 53

Liu X, 2012. Calculation and Analysis of Optimal Tilt Angle for PV/T Hybrid Collector, International Conference on Intelligent System Design and Engineering Application, 791795, doi.10.1109/ISdea.2012.702

McQuiston FC, Parker JD, Jeffrey, Spitler JD, 2004. Heating, Ventilating and Air Conditioning: Analysis and Design, 6th Edition, July

Mustarum, M, Rianse, U, Rachman A, 2015, Halu Oleo University Indonesia towards the green campus through the application of solar energy to support the electricity generation, International Journal of Smart Grid and Clean Energy, ISSN: 2315-4462 (Print) ISSN: 2373-3594 (Online), Vol. 4, No. 2, April: pp. 151-158

NASA, 2014, Surface Meteorology and Solar Energy : A Renewable Energy Resource Web Site, NASA Langley Research Center Atmospheric Science Data Center Surface meteorological and Solar Energy (SSE) web portal supported by the NASA LaRC POWER Project

Rachman A, Rianse U, Musaruddin M, Ornam $\mathrm{K}, 2015$, Technical, economical and environmental assessments of the solar $P V$ technology in Southeast Sulawesi, a developing province in eastern Indonesia, International Journal of Energy Economics and Policy, ISSN: 2146-4553, Vol 5(4) -Hal. 918-925

Sudia B, Rachman, A, 2011, The assessment of solar radiation intensity in Southeast Sulawesi based on the relative position of the sun, Jurnal Metropilar, Vol 9 , 2/4/2011, p 115 - 120, ISSN 1693-6205 